\title{
PENGARUH FAKTOR ANTESEDEN MOTIVASI, DISIPLIN, DAN KESEJAHTERAAN TERHADAP KINERJA PEGAWAI
}

\section{(THE INFLUENCE OF MOTIVATION, DISCIPLINE, AND WELFARE ANTESEDENTS ON EMPLOYEE PERFORMANCE)}

\author{
Oleh: \\ Veronica1), Siti Khadijah Koto' \\ Sekolah Tinggi Transportasi Darat (STTD) Cibitung, Bekasi1,2) \\ vcsimanjuntak@gmail.com ${ }^{1}$, sitikhadijahkoto@gmail.com ${ }^{2}$
}

Submit: 28 Apr $2020 \quad$ Review: 28 Apr 2020 Accept: 29 Apr 2020 Publish: 30 Apr 2020

\begin{abstract}
The aim of this research is to examine the factors that influence Employee Performance. The factors which are used in this study include; Employee Motivation, Discipline, and Welfare. The research data were obtained from the results of a questionnaire distributed to 103 employees as respondents. The analysis technique used is Multiple Regression Analysis with results; Motivation, Discipline, and Welfare have a positive influence on Employee Performance.
\end{abstract}

Keywords: Motivation, Discipline, Prosperity, and Official Performance.

\section{ABSTRAK}

Tujuan penelitian ini adalah bermaksud untuk menguji faktor-faktor anteseden yang mempengaruhi Kinerja Pegawai. Faktor-faktor yang digunakan dalam penelitian ini diantaranya; Motivasi, Disiplin dan Kesejahteraan. Data penelitian diperoleh dari hasil kuesioner yang dibagikan kepada 103 pegawai sebagai responden. Teknik analisis yang digunakan adalah Analisis Regresi Berganda dengan hasil; Motivasi, Disiplin, dan Kesejahteraan memiliki pengaruh positif terhadap Kinerja Pegawai.

Kata kunci: Motivasi, Disiplin, Kesejahteraan, dan Kinerja pegawai..

\section{PENDAHULUAN}

Setiap organisasi selalu menginginkan peningkatan kinerja pegawai. Namun demikian, tidak semua organisasi mendapatkan apa yang diinginkan. Harapan banyak yang tidak tercapai, artinya banyak organisasi yang mengalami pasang surut dalam hal kinerja pegawai.
Permasalahan kinerja selalu ada di setiap organisasi tidak terkecuali di Lembaga Pendidikan Tinggi. Adanya permasalahan ini menjadi bahasan yang menarik untuk diteliti (Hutagalung dan Yuli, 2019; Irawan, 2012; Utari, 2015, Pratiwi dan Darmastuti, 2014; Murtiningsih, 2012). 
Untuk mencapai hal tersebut, organisasi harus memberikan motivasi yang baik kepada seluruh pegawainya. Dengan motivasi kerja pegawai diharapkan mampu menjadi daya penggerak yang dapat menciptakan kegairahan kerja pegawai, agar pegawai mau bekerja sama secara produktif mencapai dan mewujudkan kinerja yang diharapkan (Sajangbati, 2013). Motivasi yag tinggi dapat mendorong kinerja yang tinggi pula (Ayer, 2016; Kumarawati, Suparta dan Yasa, 2017; Utari, 2015). Peran motivasi perlu dibuktikan kembali di Lembaga Pendidikan Tinggi mengingat motivasi yang begitu penting bukanlah factor dominan (Murtiningsih, 2012) bagi Satuan Polisi Pamong Praja.

Selain motivasi dibutuhkan juga adanya disiplin kerja saat melakukan pekerjaannya (Sajangbati, 2013; Hutagalung dan Triastuti, 2019). Dengan menerapkan disiplin kerja yang baik diharapkan pegawai akan memiliki sikap kesediaan dan kerelaan pegawai agar selalu memahami dan mematuhi normanorma peraturan yang berlaku disekitarnya yang merupakan hal yang sangat diharapkan. Sayangnya dalam beberapa penelitian disiplin justru tidak berpengaruh terhadap kinerja (Kumarawati, Suparta dan Yasa, 2017; Lisma, 2015; Pratiwi dan Darmastuti, 2014; Kurniawan, 2015; Utari 2015). Perbedaan ini menunjukkan makin pentingnya disiplin dan makin perlunya pembuktian ada tidaknya pengaruh disiplin di lingkungan Lembaga Pendidikan Tinggi. Hal ini tidak lepas dari temuan penelitian yang menunjukkan bahwa disiplin lebih dominan dalam mempengaruhi kinerja disbanding motivasi (Kurniawan, 2015).

Selain motivasi dan disiplin, pemenuhan hak-hak pegawai merupakan fator pendorong utama yang dapat mengarahkan pegawai untuk menunjukkan hasil kerja terbaik. Pemenuhan hak tersebut berkenaan dengan yang dinikmati seperti kompensasi (Helmi, 2009; Irawan, 2012), budaya organisasi dan gaya kepemimpinan (Dzulkifli, 2013), lingkungan kerja (Irawan 2012) yang kesemuanya mengarah kepada kesejahteraan. Pentingnya kesejahteraan untuk ditelaah tidak lepas dari temuan penelitian (Murtiningsih, 2012) yang mengemukakan bahwa kesejahteraan lebih dominan dalam mempengaruhi kinerja disbanding motivasi.

\section{TUJUAN PENELITIAN}

Tujuan penelitian adalah Pengaruh Faktor Anteseden Motivasi, Disiplin, dan Kesejahteraan Terhadap Kinerja Pegawai

\section{TELAAH LITERATUR DAN PENGEMBANGAN HIPOTESIS Kinerja Pegawai}

Kinerja artinya prestasi kerja yang dicapai seseorang. Kinerja yang tinggi dari para karyawan berfungsi mengelola faktor-faktor produksi yang lain sangat diperlukan agar perusahaan memiliki produktivitas yang tinggi sehingga dapat unggul dalam persaingan global.

Kinerja menurut Bastian (2001: 329) adalah gambaran tingkat pencapaian pelaksanaan tugas dalam upaya mewujudkan sasaran, tujuan, misi, dan visi organisasi tersebut. Sedangkan Gibson, Invancevich \& Donnely (terjemahan Jimmy Sadeli dan Bayu Prawira, 2002: 76) mengemukakan bahwa: "Kinerja adalah tingkat keberhasilan dalam melaksanakan tugas dan kemampuan untuk mencapai tujuan yang telah ditetapkan".

Mahmudi (2005: 88) mengemukakan : "Kinerja adalah merupakan suatu konstruk yang bersifat multidimensional, pengukurannya juga bervariasi pada 
kompleksitas faktor - faktor yang membentuk kinerja". Hal senada diungkap Mangkunegara (2005: 67) yang menyatakan bahwa "Kinerja adalah hasil kerja secara kualitas dan kuantitas yang dicapai pegawai dalam melaksanakan tugas sesuai tanggung jawabnya". Oleh karea itu indikator kinerja pegawai adalah Kualitas kerja, Kuantitas kerja, Kerja sama, Tanggung jawab, Inisiatif.

Setiap pemimpin sebuah organisasi pasti sudah dan akan sangat menyadari adanya perbedaan kinerja diantara karyawan-karyawannya. Karyawan yang berada di bawah control, kendali, pengawasannya pastilah berbeda dalam menghasilkan pekerjaan. Perbedaan kinerja yang utama ini disebabkan oleh adanya dua faktor (As'ad, 2008: 12), yaitu: faktor individu dan situasi kerja.

Mahmudi (2005: 88) mengemukakan faktor kinerja adalah terdiri dari lima faktor, sebagai berikut:

a. Faktor personal/individual yang meliputi pengetahuan, keterampilan, kemampuan, kepercayaan, motivasi, dan komitmen setiap individu.

b. Faktor kepemimpinan yang meliputi kualitas dalam memberikan dorongan, semangat, arahan, dukungan dan teladan.

c. Faktor tim yang meliputi kualitas saling mendukung, menyemangati, mempercayai, dan menjaga kekompakan serta keeratan tim.

d. Faktor system yang meliputi sistem kerja, fasilitas kerja atau infrastruktur dalam organisasi, proses organisasi dan budaya kinerja dalam organisasi.

e. Faktor kontekstual (situasional) yang meliputi tekanan dan perubahan lingkungan eksternal-internal.

Kinerja merupakan suatu konstruk yang bersifat multidimensional, pengukurannya juga bervariasi pada kompleksitas faktor - faktor yang membentuk kinerja (Mahmudi, 2005: 88). Adapun, indikator yang digunakan adalah Kualitas kerja, Kuantitas kerja, Kerja sama, Tanggung jawab, dan Inisiatif (Mahmudi, 2005: 88).

\section{Pengaruh Motivasi terhadap Kinerja Pegawai}

Teori mengatakan Faktor-faktor yang mengarahkan dan mendorong perilaku atau keinginan seseorang untuk melakukan sesuatu kegiatan yang dinyatakan dalam bentuk usaha yang keras akan mendorong seseorang untuk bekerja (Marihot, 2003). Motivasi dapat mendorong kinerja pegawai pada PT. Gudang Garam (Kurniawan, 2015). Motivasi yang tinggi juga dapat meningkatkan kinerja pegawai pada Direktorat Budidaya Pascapanen Florikultura Jakarta Selatan. Motivasi dapat mendorong kinerja pegawai pada Karyawan Harpindo Jaya Kudus (Irawan, 2012). Motivasi menunjukkan semakin tinggi motivasi yang diterima karyawan, maka akan meningkatkan kinerja karyawan. Motivasi dapat mendorong kinerja pegawai (Listianti, 2007) motivasi secara simultan berpengaruh signifikan terhadap kinerja pegawai karyawan.

Penggunaan motivasi tersebut harus tepat dan seimbang supaya dapat meningkatkan kesejahteraan pegawai. Kekuatan motivasi tenaga kerja untuk bekerja/berkinerja secara langsung tercermin sebagai upayanya dalam mengukur seberapa jauh seorang karyawan bekerja keras, upaya ini mungkin menghasilkan kinerja yang baik atau sebaliknya pada Lembaga Pendidikan Tinggi. Oleh karena itu diduga makin tinggi motivasi makin tinggi kinerja pegawai

H1: motivasi berpengaruh terhadap kinerja pegawai Lembaga Pendidikan Tinggi. 


\section{Pengaruh Disiplin terhadap Kinerja Pegawai}

Teori mengatakan kepatuhan untuk menghormati dan melaksanakan suatu sistem yang orang untuk tunduk pada keputusan, perintah atau peraturan yang berlaku. Dengan kata lain, disiplin adalah kepatuhan mentaati peraturan dan ketentuan yang telah ditetapkan. Disiplin sikap kesetiaan dan ketaatan seseorang atau sekelompok orang terhadap peraturan-peraturan baik tertulin maupun tidak tertulis, yang tercermin dalam bentuk tingkah laku dan perbuatan (Ayer, 2016).

Disiplin dapat meningkatkan kinerja pegawai yang baik akan senantiasa memberikan kontribusi yang baik bagi karyawan sehingga pegawai akan senantiasa memiliki kecintaan terhadap pekerjaannya (Sajangbati ,2013). Disiplin yang tinggi dapat meningkatkan kinerja pegawai pada PT. Telekomunikasi Indonesia (Persero) (Pratiwi, 2014). Disiplin dapat mendorong kinerja pegawai pada Direktorat Budidaya dan Pascapanen Florikultura Jakarta Selatan (Dzulkifli, 2013) menunjukkan bahwa kedisiplinan memiliki pengaruh signifikan terhadap kinerja pegawai

Pengaruh disiplin kerja tindakan untuk mendorong agar para anggota organisasi dapat memenuhi berbagai ketentuan dan peraturan yang berlaku dalam organisasi tersebut, disiplin ini meningkat menjadi kebiasaan berpikir baik, positif, bermakna, dan memandang jauh ke depan. Disiplin mengikuti dan menaati peraturan, melainkan sudah meningkat menjadi disiplin berpikir yang mengatur dan mempengaruhi seluruh aspek kehidupan di Lembaga Pendidikan Tinggi. Oleh karena itu diduga makin Disiplin kinerja pegawai makin tinggi.

H2: Disiplin berpengaruh terhadap kinerja pegawai Lembaga Pendidikan Tinggi.

\section{Pengaruh Kesejahteraan Terhadap Kinerja Pegawai}

Teori mengatakan diberikan berdasarkan kebijaksanaan untuk mempertahankan dan memperbaiki kondisi fisik dan mental karyawan supaya produktivitas kerjanya meningkat akan mendorong seseorang untuk lebih giat dalam bekerja (Helmi, 2009). Kesejahteraan dapat meningkatkan kinerja pegawai Dinas Kesehatan Kabupaten Bangli. Kesejahteraan yang tinggi juga dapat meningkatkan kinerja pegawai Harpindo Jaya Kudus (Irawan, 2012). Kesejahteraan dapat mendorong kinerja pegawai (Siska, 2005). Kesejahteraan mempunyai pengaruh signifikan terhadap kinerja pegawai mempunyai pengaruh dominan terhadapkinerja di Dinas Kesehatan Kabupaten Bangli. Kesejahteraan dapat meningkatkan kinerja pegawai pada penelitiannya (Listianti, 2007) Kesejahteraan secara simultan dapat berpengaruh terhadap kinerja karyawan.

Pengaruh kesejahteraan kerja kualitas dan kuantitas dari suatu hasil kerja individu dalam suatu aktivitas atau periode tertentu yang merupakan hal yang dilakukan pegawai untuk menerapkan disiplin kepada pegawai. Penerapan disiplin dimaksudkan supaya pegawai bertanggung jawab atas pekerjaan pada Lembaga Pendidikan Tinggi. Oleh karena itu diduga makin tinggi tingkat kesejahteraan kinerja pegawai makin baik. H3: Kesejahteraan berpengaruh terhadap kinerja pegawai Lembaga Pendidikan Tinggi.

Dari uraian di atas merupakan salah satu cara agar penelitian yang dilakukan bisa dimengerti dan mudah di pahami. Dengan memberikan pedoman langkah yang diambil dalam penulisan ini adalah dengan memberikan kerangka dalam penulisan tesis yang dikenal dengan kerangka pemikiran. Dalam model 
penelitian ini yang bersifat asosiatif/hubungan yang menggunakan pendekatan analisis statistik regresi untuk mengetahui pengaruh dari tiga variabel independen terhadap satu variable dependen, digambarkan dalam bentuk bagan kerangka pemikiran seperti berikut.

Gambar 1

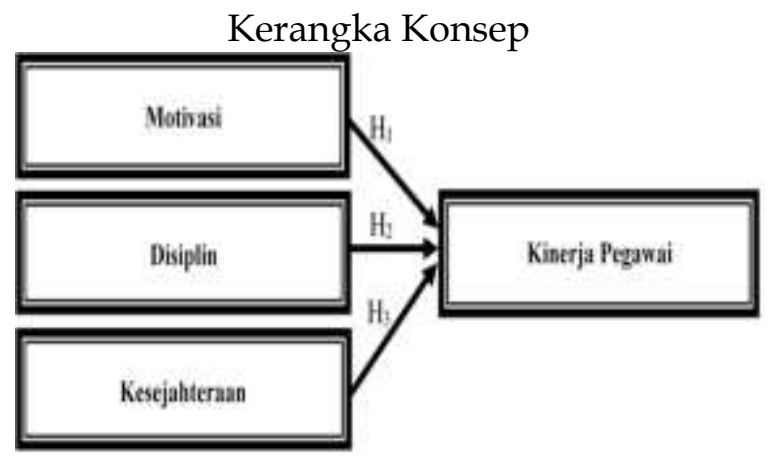

\section{METODE PENELITIAN \\ Sampel Penelitian}

Penelitian dilakukan di Lembaga Pendidikan Tinggi di Bekasi. Data penelitian diperoleh dengan menyebarkan kuesioner kepada 103 responden (pegawai) sebagai sampel penelitian.

\section{Operasionalisasi Variabel}

Dalam penelitian ini, variabel yang digunakan mencakup sebagai berikut:

\section{Tabel 1}

Operasionalisasi Variabel

\begin{tabular}{|c|c|}
\hline Defintisi & Indikatex \\
\hline 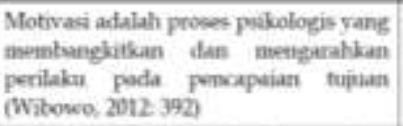 & $\begin{array}{l}\text { 1. Ketuhnhan Protasi } \\
\text { 2. Ketminuhan Kumasa } \\
\text { 3. Ketutnhan Afliani }\end{array}$ \\
\hline 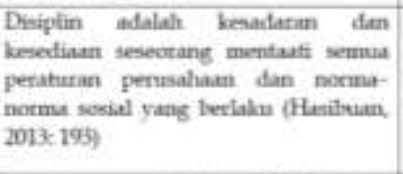 & 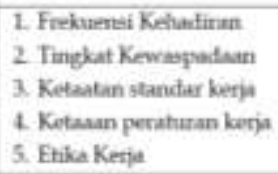 \\
\hline 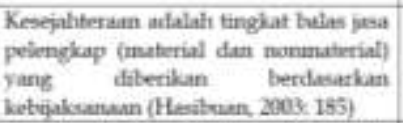 & $\begin{array}{l}\text { 1. Fianouni } \\
\text { 2. Fisilitas } \\
\text { 3. Pelayinan }\end{array}$ \\
\hline 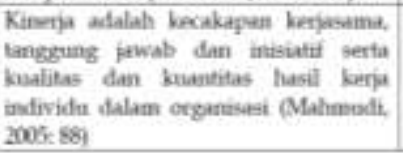 & $\begin{array}{l}\text { 1. Kualitas Kerja } \\
\text { 2. Kuantitas Kerja } \\
\text { 3. Kerfasans } \\
\text { 1. Timeggung lawab } \\
\text { 5. Inisiatif }\end{array}$ \\
\hline
\end{tabular}

\section{Metode Analisis}

Analisis menggunakan regresi linier ganda. Tahapan analisis meliputi uji validitas reliabilitas, analisis deskriptif, uji asumsi klasik, uji model dan uji hipotesis.

\section{Uji Validitas-Reliabilitas}

Suatu instrument dikatakan valid apabila instrument tersebut dapat mengukur apa yang seharusnya diukur (Kountur, 2005). Pada penelitian ini pengujian validitas dilakukan terhadap semua instrumen yang terdapat dalam kuisioner. Uji validitas dengan membandingkan p-value dengan level of significant sebesar 5\% yaitu: jika p-value < alpha 0,05 maka item pernyataan valid, dan sebaliknya.

Uji reliabilitas dalam penelitian ini dilakukan uji internal consistency reliability dengan menggunakan nilai dari Cronbach Alpha. Cronbach's Alpha yang cukup dapat diterima (acceptable) adalah yang bernilai 0,60 sampai 0,70 atau lebih (Sekaran, 2006).

\section{Analisis Deskriptif}

Analisis deskriptif dilakukan dengan mencarai rerata nilai jawaban minimum dan maksimum. Selain itu juga dicari rerata variable, median untuk selanjutnya dicari kecenderungan kategorinya.

\section{Uji Asumsi Klasik}

Empat uji asumsi klasik meliputi asumsi normalitas, heteroskedastisitas, multikolinearitas, dan autokorelasi. Dalam uji asumsi klasik gambaran hasil penelitian mendekati atau sama dengan kenyataan sangat diharapkan.

a. Uji Normalitas

Pengujian dilakukan dengan Grafik Normal P-P Plot dan KolmogorovSmirnov Test. Berdasarkan Grafik Normal P-P Plot, uji normalitas dapat dideteksi dengan melihat penyebaran 
data (titik) pada sumbu diagonal dari grafik normal dimana asumsi terpenuhi jika data residual menyebar di sekitar an mengikuti arah garis diagonalnya. Berdasar K-S Test, normalitas terpenuhi jika signifikansi data residual $>0,05$.

b. Uji Multikolinearitas

Multikolinearitas terjadi jika nilai Variance Inflation Factor (VIF) lebih besar dari 10 atau nilai Tolerance lebih kecil 0,10.

c. Uji Autokorelasi

Uji autokorelasi dengan Durbin Watson terpenuhi jika nilai Durbin Watson berkisar diantara nilai batas atas (dU): a) Tidak ada autokorelasi positif jika $0<\mathrm{d}<\mathrm{dL}$; b) Tidak ada autokorelasi positif jika $\mathrm{dL} \leq \mathrm{d} \leq \mathrm{dU}$; $\mathrm{c}$ ) Tidak ada autokorelasi negative jika 4$\mathrm{dL}<\mathrm{d}<4$; d) Tidak ada autokorelasi negative jika 4-dU $\leq \mathrm{d} \leq 4-\mathrm{dL}$; e) Tidak ada autokorelasi (positif atau negatif) jika dU $<$ d $<4$-dU (Gujarati, 2003).

d. Uji Heteroskedastisitas

Model yang baik adalah yang tidak terjadi heteroskedastisitas (Ghozali, 2012). Uji Heterokedastisitas pada penelitian ini dilakukan melalui metode Glejser Test. Asumsi terpenuhi jika nilai Sig. > 0,05.

Uji kedua menggunakan grafik scatterplot. Asumsi terpenuhi jika tidak terdapat pola yang jelas, serta titik-titik menyebar diatas dan dibawah angka nol (0) pada sumbu Y.

\section{Uji Model}

a. Koefisien Determinasi $\left(\mathrm{R}^{2}\right)$

Untuk mengukur level kemampuan model yaitu idependen terhadap dependen. Nilai koefisien determinasi ialah di antara angka nol dan satu. Nilai $\mathrm{R}^{2}$ yang kecil berarti variabelvariabel independen dalam menjelaskan variasi variabel dependen kemampuannya sangat terbatas. Nilai yang mendekati 1 berarti variabelvariabel independen memberikan hampir semua variasi yang diperlukan untuk memprediksi variasi variabel dependen. Penggunaan nilai R2 adalah untuk melakukan pengukuran terhadap tingkat kemampuan model dalam memberikan penjelasan atas variabel independen, tapi karena kelamahan mendasar yang terkandung di dakam R2 yaitu adanya bias terhadap jumlah variabel independen yang dimasukkan kedalam model, maka dalam penelitian ini digunakan adjusted R2 berkisar antara 0 dan 1 . Jika nilai adjusted R2 semakin mendekati 1 maka semakin baik kemampuan model tersebut dalam menjelaskan variabel dependen. (Imam Ghozali, 2012: 97).

b. Uji F

Dengan melakukan Uji F maka akan ditunjukkan apakah semua variabel independen memiliki pengaruh secara bersamaan terhadap variabel dependen (Ghozali, 2012: 98). Pelaksanaan dalam pengujian ini dengan memakai significance level $0,05(a=5 \%)$. Model dikatakan layak jika nilai sig F. (signifikansi) < 0,05.

\section{Uji Hipotesis}

a. Persamaan Regresi Linier Berganda Penggunaan model persamaan regresi yang akan digunakan dalam pengujian hipotesis dirumuskan dan kemudian dilakukan analisis dengan 
SPSS 23 dengan tingkat signifikansi 5\%

$(\alpha=0.05)$ sebagai berikut:

$\mathrm{Y}=\mathrm{a}+\mathrm{b} 1 \mathrm{X} 1+\mathrm{b} 2 \mathrm{X} 2+\mathrm{b} 3 \mathrm{X} 3$ .1

Keterangan:

$\mathrm{a}=$ konstanta

$\mathrm{b}=$ koefisien regresi

$\mathrm{Y}=$ Variabel terikat Kinerja

$\mathrm{X} 1=$ Variabel bebas Motivasi

X2 = Variabel bebas Disiplin

X3 $=$ Variabel bebas Kesejahteraan

b. Uji t

Pengujian dilaksanakan dengan menggunakan significance level 0,05 $(a=5 \%)$. Apabila probabilitas sig. $t$ (signifikansi) < 0,05 (a) atau thitung > ttabel artinya hipotesa terbukti.

\section{HASIL PENELITIAN DAN PEMBAHASAN \\ Hasil Penelitian \\ Uji Validitas-Reliabilitas}

Seluruh item pernyataan di setiap variable memiliki $p$-value $<0,05$ yang berarti item-item yang digunakan adalah valid. Artinya item-item pernyataan yang digunakan dalam instrumen penelitian memiliki validitas konstruk. Dengan kata lain terdapat konsistensi internal dalam pernyataan-pernyataan tersebut sehingga dapat membentuk konstruk dari Motivasi, Disiplin, Kesejahteraan, dan Kinerja Pegawai dan dapat dinyatakan valid.

Nilai koefisien Cronbach's Alpha untuk masing-masing item dari Motivasi, Disiplin, Kesejahteraan dan Kinerja Pegawai > 0,60, yang berarti Cronbach's Alpha dapat diterima (acceptable) atau konstruk reliable. Maka dapat disimpulkan jawaban rersponden terhadap pernyataanpernyataan yang digunakan untuk mengukur Variable Independen terhadap Variabel Dependen adalah konsisten dan konstruk dapat dipercaya (reliable).

\section{Deskripsi Variabel}

Variabel dependen (Y) Kinerja Pegawai memiliki kisaran rerata nilai jawaban minimum dari keseluruhan responden adalah sebesar 3,800 dengan nilai maksimum sebesar 5,00. Nilai rerata jawaban yang dihasilkan adalah sebesar 4,47 berada pada area maksimum sehingga dapat diartikan bahwa Kinerja pegawai pada instansi terkait telah cukup tinggi.

Variabel independen Motivasi memiliki nilai minimum jawaban dari keseluruhan responden sebesar 3,00 dengan nilai maksimum sebesar 5,00. Nilai rerata sebesar 4,21 dengan nilai standar deviasi sebesar 0,514, dapat diartikan tingkat motivasi para pegawai di Lembaga Pendidikan Tinggi telah cukup baik.

Disiplin menghasilkan nilai minimum dari keseluruhan responden sebesar 3,00 dengan nilai maksimum sebesar 5,00. Nilai rerata yang dihasilkan memiliki nilai 4,46 dengan standar deviasi sebesar 0,43 sehingga dapat diartikan bahwa tingkat kedisiplinan para pegawai pada Lembaga Pendidikan Tinggi telah cukup tinggi.

Kesejahteraan menghasilkan nilai minimum dari keseluruhan responden sebesar 3,80 dengan nilai maksimum sebesar 5,00. Nilai rerata yang dihasilkan memiliki nilai 4,43 dengan standar deviasi sebesar 0,30. Dapat diartikan bahwa kesejahteraan para pegawai pada Lembaga Pendidikan Tinggi telah cukup tinggi.

\section{Uji Asumsi}

a. Uji Asumsi Normalitas

Titik-titik pada grafi tersebar disekitar dan mengikuti arah garis diagonal. Nilai residual uji normalitas memiliki signifikansi $>0.05$. Dua hal tersebut berarti model regresi yang digunakan mempunyai standar error yang normal. 
Uji secara grafis (Normal P-P Plot) dan matematis (K-S Test) berikut:

Gambar 2

Hasil Uji Normalitas

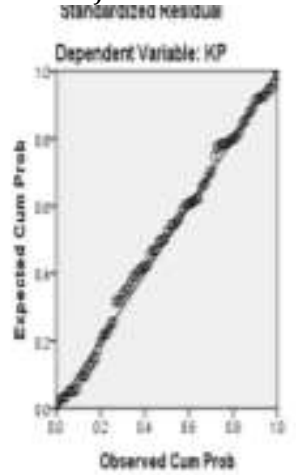

\begin{tabular}{|c|c|c|}
\hline Variabel & Sig & Keputusin \\
\hline Standandizal Rrsitual (KP) & 0,200 & Nermal \\
\hline
\end{tabular}

Sumber : data diolah, 2020

b. Uji Multikolinearitas

Hasil pegujian asumsi kedua adalah sebagai berikut:

Tabel 2

Pengujian Multikolinearitas

\begin{tabular}{|c|c|c|}
\hline \multirow{2}{*}{$\begin{array}{l}\text { Variabel } \\
\text { Independen }\end{array}$} & \multicolumn{2}{|c|}{ Dependen: Kiervis Peganuli } \\
\hline & VIF & Keputhun \\
\hline Matinasi $\left(\alpha_{0}\right)$ & 1,57 & Tidak ada multiblineantas \\
\hline Dosplan (X) & 2546 & Tidak ada multkolineantas \\
\hline Kescilthous $\left(\chi_{3}\right)$ & 1786 & Tidak ada multkolineanits \\
\hline
\end{tabular}

Sumber : data diolah, 2020

Variabel independen model mempunyai nilai VIF kurang dari 10 yang berarti variabel independen yang digunakan pada model persamaan regresi tidak ada multikolinearitas.

c. Uji Autokorelasi

Dasar pengambilan keputusan uji autokorelasi lebih jelasnya ditampilkan pada tabel berikut ini :
Tabel 3

Keputusan Uji Autokorelasi

\begin{tabular}{|c|c|c|c|c|c|c|c|c|}
\hline Model & $y$ & $x^{\prime}$ & d & d & Ldt & 14. & DW & Knitupulan \\
\hline $\mathrm{KP}$ & 163 & 3 & 1616 & 1732 & 2266 & 2384 & 2115 & $\begin{array}{l}\text { Tidis ada } \\
\text { antolotedasi }\end{array}$ \\
\hline
\end{tabular}

Sumber : data diolah, 2020

Nilai batas bawah (dL) yang dihasilkan pada model persamaan adalah sebesar 1,6196, dengan batas atas (dU) sebesar 1,7392. Hasil uji durbin watson statistik didapat sebesar 2,118 berada di area $\mathrm{du}<\mathrm{dw}<$ 4-du, atau berada di area tidak ada autokorelasi. Maka tidak ada autokorelasi pada model regresi.

Gambar 3

Pengujian Autokorelasi

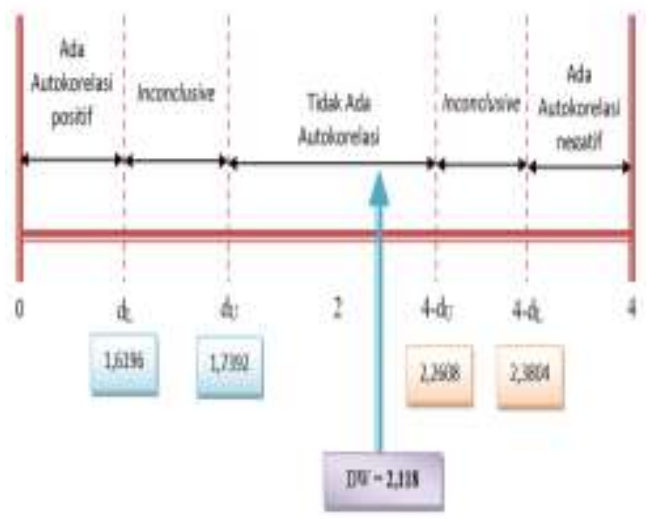

Sumber : data diolah, 2020

d. Uji Heteroskedastisitas

Hasil pengujian heteroskedastisitas ditunjukkan pada tabel berikut :

Tabel 4

Hasil Pengujian Heteroskedastisitas

\begin{tabular}{|c|c|c|}
\hline \multirow{2}{*}{$\begin{array}{c}\text { Variabel } \\
\text { Independen }\end{array}$} & \multicolumn{2}{|c|}{ Depender: Kinerja Pegawai } \\
\hline & Sigh & Keputusan \\
\hline Matinsi $\left(X_{1}\right)$ & 0,187 & Thiak ada Hetero \\
\hline Disquin $\left(\chi_{\theta}\right)$ & 0,758 & Tidak ada Hetero \\
\hline Rosquituman $\left(X_{2}\right)$ & 0,829 & Tidaks ada Hetero \\
\hline
\end{tabular}

Sumber : data diolah, 2020 
Berdasarkan tabel diatas, diketahui bahwa seluruh variabel independen yaitu Motivasi, Disiplin dan Kesejahteraan memiliki nilai sig. > 0,05 . Artinya varians error dinyatakan homogen. Selanjutnya disimpulkan tidak terdapat permasalahan heteroskedastisitas. Dengan demikian asumsi atas heteroskedastisitas pada model persamaan regresi telah terpenuhi.

Hasil pengujian Heterokedastisitas diperoleh dengan gambar sebagai berikut:

\section{Gambar 4}

Pengujian Heterokedastisitas

\section{Scatterplot}

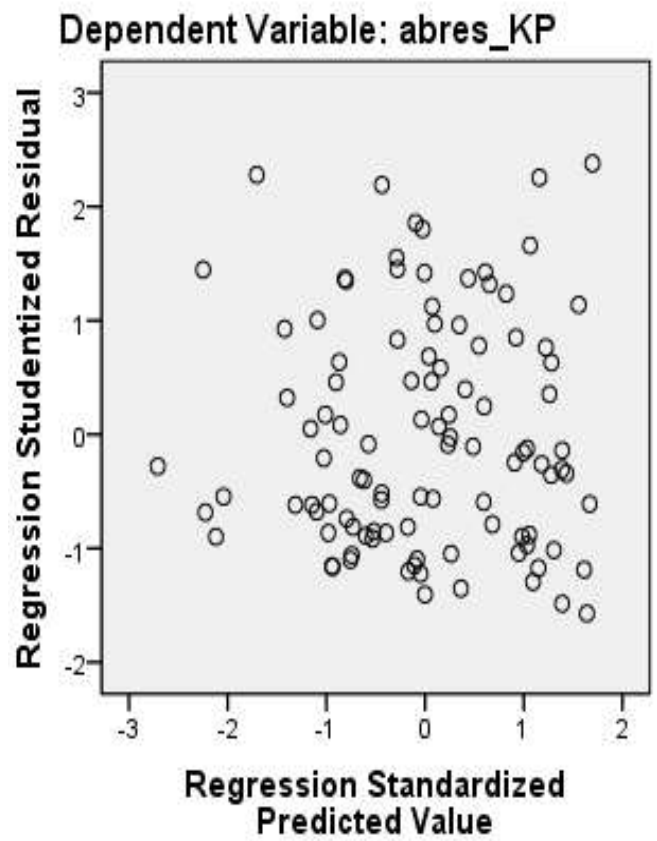

Sumber : data diolah, 2020

Berdasarkan

hasil

uji

heteroskedastisitas pada model diatas diketahui tidak ada pola jelas, serta titik-titik terurai di atas dan di bawah angka 0 (nol) sumbu Y, maka dapat disimpulkan tidak terjadi heteroskedastisitas.

\section{Uji Model}

a. Koefisien Determinasi (Pengujian $\mathrm{R}^{2}$ dan Adjusted R ${ }^{2}$ )

Koefisien determinasi $\left(\mathrm{R}^{2}\right)$ mengukur kemampuan model dalam menerangkan variasi variabel dependen. Nilai $\mathrm{R}^{2}$ (r-squared) yang kecil berarti kemampuan independen dalam menjelaskan variasi dependen amat terbatas. Nilai yang mendekati satu berarti independen memberikan hampir semua informasi yang dibutuhkan untuk memprediksi variasi dependen (Ghozali, 2022).

Tabel 5

Hasil Uji R² dan Adjusted R²

\begin{tabular}{|c|c|c|}
\hline \multirow{2}{*}{$\begin{array}{l}\text { Varibled } \\
\text { Independea }\end{array}$} & \multicolumn{2}{|c|}{ Depender: Kiatrji Prgawai } \\
\hline & 8 & difinted / \\
\hline WV. DS. $D S$ & 0.39 & 0,337 \\
\hline
\end{tabular}

Sumber : data diolah, 2020

Dari hasil pengujian regresi model diatas didapat nilai R2 adalah sebesar 0,391 pada model yang digunakan. Artinya variabel dependen hanya mampu dijelaskan oleh variasi dari variabel independennya yaitu sebesar $39,1 \%$, sedangkan sisanya sebesar $60,9 \%$ dapat dijelaskan oleh faktorfaktor lain yang tidak diikutsertakan dalam pengujian.

b. Uji F (Uji Kelayakan Model)

Uji statistik $F$ pada dasarnya menunjukkan apakah semua variabelindependen yang dimasukkan dalam model mempunyai pengaruh secara bersama-samaterhadap variabel dependennya (Ghozali. 2012). Apabila analisis menggunakan uji $\mathrm{F}$ menunjukkan bahwa semua variabel independen secara simultan 
merupakan penjelas yang signifikan terhadap variabel dependen.

Tabel 6

Hasil Uji F (Kelayakan)

\begin{tabular}{|c|c|c|c|}
\hline \multirow{2}{*}{$\begin{array}{c}\text { Variabel } \\
\text { Independen }\end{array}$} & \multicolumn{3}{|c|}{ Dependen Kinerja Pegawai } \\
\cline { 2 - 4 } & Fimat & Sig. & Kesimpulan \\
\hline MV, DS, KS & 4,300 & 0,001 & Hoditiolak \\
\hline
\end{tabular}

Sumber : data diolah, 2020

Hasil Uji F menggunakan analisis varians (ANOVA) bahwa nilai Fhitung yang diperoleh pada model yang digunakan sebesar 4,300 dengan nilai sig. yang dihasilkan sebesar 0,001 yang mampu menyatakan bahwa model layak untuk menjelaskan pegaruh independen yaitu Motivasi, Disiplin dan Kesejahteraan Kerja terhadap Kinerja Pegawai.

\section{Uji Hipotesis}

a. Persamaan Regresi Ganda

Hasil analisis regresi linier ganda adalah sebagai berikut:

Tabel 7

Model dan Uji t (Uji Parsial)

\begin{tabular}{|c|c|c|c|}
\hline \multirow{2}{*}{$\begin{array}{l}\text { Variablel } \\
\text { Isdependen }\end{array}$} & \multicolumn{2}{|c|}{ Depeaden: Kiserja Peguwai } & \multirow{2}{*}{$\begin{array}{l}\text { Kesimpulan } \\
\text { Hiptesis }\end{array}$} \\
\hline & Koefisien & Sig. & \\
\hline (Coostut) & 1.108 & 0,000 & \\
\hline$M V\left(x_{1}\right)$ & 0300 & 0,01 & 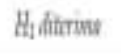 \\
\hline$D S\left(x_{0}\right)$ & 0014 & 0,033 & H: Aftriver \\
\hline$K S\left(X_{1}\right)$ & 020 & 0,02 & Hititriws \\
\hline
\end{tabular}

Sumber : data diolah, 2020

Model persamaan regresi hasil penelitian adalah sebagai berikut:

$\mathrm{Y}=1,108+0,300 \mathrm{X} 1+0,014 \mathrm{X} 2+$ 0,200X3 b. Pengujian Hipotesis

1) Uji Hipotesis 1:

Variabel Motivasi

menghasilkan nilai koefisien yang positif terhadap perilaku Kinerja Pegawai (Y) yaitu sebesar 0,300 dan nilai probabilita yang dihasilkan adalah sebesar 0,001. Nilai probabilita yang dihasilkan sebesar 0,001 adalah lebih kecil dari tingkat signifikan 5\% (0,001 < a 0,05) dapat disimpulkan adanya pengaruh Motivasi terhadap Kinerja Pegawai yang signifikan, maka hipotesa 1 diterima.

2) Uji Hipotesis 2:

Pengujian pada hipotesis kedua mengenai pengaruh Disiplin terhadap Kinerja Pegawai menghasilkan nilai koefisien positif sebesar 0,014 dengan nilai probabilita (sig.) sebesar 0,033. Nilai probabilita yang dihasilkan lebih kecil dari tingkat signifikan $5 \%$ atau $0,033<$ a 0,05 sehingga dapat menyatakan adanya pengaruh yang signifikan antara Disiplin terhadap Kinerja Pegawai, maka hipotesa 2 diterima.

3. Hipotesis3 :

Hasil yang didapatkan dalam pengujian hipotesis ketiga menunjukkan nilai koefisien yang positif yaitu sebesar 0,200 dengan nilai probabilita (sig.) sebesar 0,002. Nilai probabilitas yang dihasilkan lebih kecil dari tingkat signifikan 5\% atau 0,002 < a 0,05 sehingga dapat menyatakan adanya pengaruh yang signifikan antara Kesejahteraan terhadap Kinerja Pegawai, maka hipotesis 3 diterima. 
Pembahasan

\section{Analisis Pengaruh Motivasi Terhadap Kinerja Pegawai}

Pada hasil pengujian antara variabel Motivasi terhadap Kinerja Pegawai menunjukkan nilai koefisien positif yang dihasilkan sebesar 0,300 dapat mengasumsikan ketika terjadi peningkatan pada motivasi maka akan diikuti dengan peningkatan kinerja pegawai. Hal ini dapat dilihat pada nilai rerata jawaban responden pada variabel motivasi yang berada pada kisaran setuju dan sangat setuju.

Hasil tersebut sekaligus membuktikan pentingnya motivasi yang diberikan kepada para pegawai dalam melakukan pekerjaan guna menunjang kinerja para pegawai itu sendiri agar mencapai kinerja yang optimal khususnya pada Lembaga Pendidikan Tinggi tempat dilakukannya penelitian.

Hasil penelitian ini sejalan dengan penelitian yang dilakukan oleh Irawan (2012) yang melakukan penelitian pada perusahaan Harpindo Jaya dan oleh Kurniawan (2015) yang melakukan penelitian pada Direktorat Pascapanen Florikultura. Kedua penelitian tersebut menemukan adanya pengaruh yang signifikan pemberian motivasi kepada para karyawan terhadap kinerja para karyawan tersebut. Semakin tinggi tingkat motivasi yang diberikan akan semakin meningkatkan kinerja para pegawai tersebut.

Pimpinan seharusnya lebih memperhatikan motivasi pegawainya selain itu dimungkinkan bukan hanya dilakukan dengan peningkatan motivasi kerja saja, tetapi perlu diperhatikan juga aspek kemampuan yang dimiliki oleh seorang pegawai.

\section{Analisis Pengaruh Disiplin Terhadap Kinerja Pegawai}

Hipotesa kedua dalam penelitian ini menemukan adanya pengaruh yang signifikan tingkat Disiplin terhadap kinerja pegawai pada Lembaga Pendidikan Tinggi. Nilai koefisien positif yang dihasilkan sebesar 0,014 dapat mengasumsikan adanya peningkatan pada kinerja para pegawai setiap terjadi peningkatan pada disiplin para pegawai tersebut atau sebaliknya.

Penerapan kedisiplinan dalam lingkungan kerja terbukti pada Lembaga Pendidikan Tinggi sangat memberikan kontribusi yang besar bagi kinerja para pegawai itu sendiri guna menunjang visi,misi serta tujuan sebuah instansi pada umumnya.

Sejalan dengan penelitian yang dilakukan oleh Pratiwi (2014) yang melakukan peneliian pada PT Telekomunikasi Indonesia dan menemukan adanya pengaruh yang signifikan tingkat disiplin terhadap kinerja para pegawai pada instansi tersebut. Kedisiplinan inilah yang kemudian meningkat menjadi sebuah pola fikir atau kebiasaan berperilaku dalam lingungan kerja dan mengarahkan pada hal-hal yang positif, bermakna dan memiliki wawasan luas, sehingga mampu menciptakan kenyamanan pada Lembaga Pendidikan Tinggi.

Mengadakan control disiplin dari absensi kehadiran untuk disiplin waktu, menerapkan peraturan pekerjaan dan hal lainnya untuk melihat efektifitas disiplin karawan sehingga kinerja pegawainya bisa meningkat.

\section{Analisis Pengaruh Kesejahteraan Terhadap Kinerja Pegawai \\ Hipotesis terakhir dalam penelitian ini yaitu mengenai pengaruh Kesejahteraan pegawai terhadap Kinerja para pegawai di}


lembaga pendidikan tinggi yang menghasilkan nilai koefisien positif yang dihasilkan sebesar 0,200 dapat menjelaskan adanya peningkatan pada kinerja pegawai ketika terjadi peningkatan dalam kesejahteraan atau bisa sebaliknya.

Hasil penelitian ini memberikan temuan akan pentingnya perhatian yang diberikan pada Kesejahteraan para pegawai, khususnya tempat dimana penelitian ini dilakukan, yaitu Lembaga Pendidikan Tinggi guna meningkatkan kinerja para pegawai itu sendiri. Seiring terjadinya peningkatan pada kondisi fisik serta mental pegawai melalui kesejahteraan yang diberikan oleh instansi, maka akan dengan sendirinya mendorong para pegawai untuk lebih menunjukkan kinerja maksimalnya dalam menyelesaikan pekerjaan.

Hasil penelitian ini mendukung penelitian Irawan (2012) yang melakukan penelitian pada PT Harpindo Jaya dan menemukan adanya pengaruh yang signifikan antara Kesejahteraan terhadap kinerja para pegawai. Semakin tinggi kesejahteraan yang diterima oleh pegawai akan memiliki efek peningkatan terhadap kinerjanya.

Pimpinan seharusnya memperhatikan kesejahteraan yang diterima pegawai selama ini karena dengan kesejahteraan yang tercukupi akan menimbulkan kepuasan kerja dan secara tidak langsung akan berdampak terhadap peningkatan kinerja pegawai.

\section{KESIMPULAN}

Berdasarkan hasil penelitian yang dilakukan pada sejumlah responden yang bekerja pada lembaga pendidikan tinggi guna mengetahui pengaruh factor anteseden terhadap Kinerja Pegawai lebih lanjut dibuat kesimpulan factor anteseden yang diteliti yaitu Motivasi, Disiplin, dan kesejahteraan semuanya berpengaruh terhadap Kinerja dengan motivasi menjadi penyebab utama.

\section{SARAN}

Berikut ini merupakan saran dari hasil penelitian yang ditujukan untuk berbagai pihak, terlebih kepada instansi terkait yang akan meneliti seberapa pentingnya peran kinerja pegawai dalam menciptakan efektifitas dan efisiensi dalam penyelesaian pekerjaan. Berikut adalah beberapa saran dari penelitian ini :

1. Hasil yang didapatkan pada penelitian ini diharapkan mampu memberikan gambaran mengenai transparansi pada Lembaga Pendidikan Tinggi dalam melaksanakan kinerja dan memberikan dampak yang positif bagi masyarakat pada umumnya.

2. Diharapkan mampu terus memperhatikan hal-hal yang lebih mampu menunjang kinerja serta kenyamanan para pegawai dalam melaksanakan pekerjaan.

3. Penelitian selanjutnya sebaiknya dalam menyebarkan kuisioner tidak hanya pada satu cabang Sekolah atau satu instansi saja, namun mampu lebih menyeluruh dan lebih luas cakupan ruang lingkup penelitiannya.

4. Peneliti selanjutnya diharapkan dapat memperluas dan memperdalam objek dan ruang lingkup penelitian dengan menambah jumlah variabel dan memilah objek yang akan diteliti.

\section{DAFTAR PUSTAKA}

A. A Anwar Prabu Mangkunegara. 2005. Manajemen Sumber daya Manusia Perusahaan. Bandung: PT Remaja Rosdakarya

Annisa Pratiwi dan Ismi Darmastuti. 2014. "Pengaruh Motivasi dan Disiplin Kerja Terhadap Kinerja Pegawai (Studi 
Pada PT. Telekomunikasi Indonesia, Tbk Wilayah Telkom Pekalongan)". Diponegoro Journal of Management. Volume 3, Nomor 4, Tahun 2014.

As'ad, 2008. Psikologi Industri, Seri Umum. Sumber Daya Manusia. Yogyakarta: Edisi 4. Liberty

Bastian. 2001. Metode Penelitian, Yogyakarta : Pustaka Pelajar

E. Murnitingsih. 2012. "Pengaruh Motivasi, Kesejahteraan dan Fasilitas Kerja terhadap Kinerja Anggota Satuan polisi Pamong Praja Kabupaten Kediri". Naskah Publikasi.uniskakediri.ac.id

Ghozali Imam 2012. Aplikasi Analisis Multivariate dengan program IBM SPSS. Semarang: Badan Penerbit Universitas Diponegoro.

Gujarati, Damodar, 2003. Ekonometri Dasar. Terjemahan: Sumarno Zain, Jakarta: Erlangga.

Hariandja, Marihot Tua Efendi dan Yovita Hardiwati. 2003. Manajemen sumber daya manusia: pengadaan, pengembangan, pengkompensasian, dan peningkatan produktivitas pegawai. Jakarta: Grasindo.

Hasibuan, Malayu S. P 2003. Manajemen Sumber Daya Manusia, Jakarta : PT.Bumi Aksara.

Helmi. 2009. Pengaruh lingkungan Kerja dan Kompensasi Terhadap Kinerja Karyawan.

Hendra Kurniawan. 2015. "Pengaruh Kepuasan Kerja, Motivasi Kerja dan Kedisiplinan Terhadap Kinerja Karyawan PT. Garam (Persero)". eJournal IImu Manajemen Magistra, Vol 1 No 2 (2015).

Irawan. 2012. "Pengaruh Kompensasi, Semangat Kerja dan Lingkungan Kerja Terhadap Kinerja Karyawan Pada Harpindo Jaya Kudus". Skripsi. Fakultas Ekonomi Universitas Muria Kudus.

Ivonne AS Sajangbati. 2013. "Motivasi, Disiplin, dan Kepuasan Pengaruhnya Terhadap Kinerja Pegawai". Jurnal Riset Ekonomi, Manajemen, Bisnis dan Manajemen, Universitas Sam Ratulangi.
James L. Gibson, John M. Ivancevich, dan James H. Donnelly, Jr. 2002. Organizations: Behaviour, Structure and Process. terjemahan Jimmy Sadeli dan Bayu Prawira, Jakarta: Salemba

Johanes Eliezer Ayer. 2016. "Pengaruh Motivasi dan Disiplin Kerja Terhadap Pegawai pada Dinas Pertanian Kabupaten Supiori". YPI Rori - AgriSosioEkonomi, 2016 ejournal.unsrat.ac.id

Kountur, Ronny. 2005. Metode Penelitian untuk Penulisan Skripsi dan Tesis. Jakarta: PPM.

Mahmudi. 2005. Manajemen Kinerja Sektor Publik, Edisi Kedua, Yogyakarta, UPP STIM. YKPN.

Meribet Hutagalung, Yuli Triastuti. 2019. "Pengaruh Lingkungan, Motivasi dan Disiplin Terhadap Kinerja Karyawan pada PT. Anugerah Abadi Bersama", Jurnal Pengembangan Wiraswasta, Vol. 21 No. 2 - Aug 2019. DOI: http://dx.doi.org/10.33370/jpw.v21i2. $\underline{328}$

Muhammad Dzulkifli. 2013. Pengaruh Gaya Kepemimpinan, Motivasi, Disiplin Kerja, Kompetensi dan Budaya Organisasi Terhadap Kinerja Pegawai.

Mulyanto, H. dan Wulandari, A. 2010. Penelitian: Metode dan Analisis, Semarang. CV. AGUNG.

Nur Lisma. 2015. "Hubungan Antara Disiplin Kerja dengan Kinerja Karyawan PT Ambassador Garmindo". Naskah Publikasi. Fakultas Psikologi Universitas Muhammadiyah Surakarta.

Raka Kumarawati, Gede Suparta, Suyatna Yasa. 2017. "Pengaruh Motivasi Terhadap Disiplin dan Kinerja pada Sekretariat Daerah Kota Denpasar". JAGADHITA: Jurnal Ekonomi \& Bisnis, Vol. 4 No. 2. September 2017. DOI: 10.22225/jj.4.2.224.63-75.

Sekaran, Uma. 2006. Metode Penelitian Untuk Bisnis I. Edisi 4, Jakarta : Salemba Empat.lding Approach; third. 
Utari. 2015. "Pengaruh Motivasi, Kepemimpinan dan Disiplin Terhadap Kinerja Pegawai (Studi Kasus pada Dinas Pendapatan Pengelolaan Keuangan dan Aset Daerah Wonogiri", Naskah Publikasi,
Universitas Surakarta.

Muhammadiyah

Wibowo. 2010. Manajemen Kinerja. Yogyakarta : Pustaka Pekajar. 